\title{
THERAPEUTIC POTENTIAL OF VEGF AND VEGF-DERIVED PEPTIDE IN PERIPHERAL NEUROPATHIES
}

\author{
A. VERHEYEN, ${ }^{\text {à }}$ E. PEERAER, ${ }^{a \dagger}$ D. LAMBRECHTS, ${ }^{\mathrm{b}, \mathrm{c}}$ \\ K. POESEN, ${ }^{c, d}$ P. CARMELIET, ${ }^{c, d}$ M. SHIBUYA, ${ }^{e}$ \\ I. PINTELON, ${ }^{f}$ J.-P. TIMMERMANS, ${ }^{f}$ R. NUYDENS ${ }^{a}$ AND \\ T. MEERT ${ }^{\mathrm{a} *}$ \\ ${ }^{a}$ Department of Neuroscience, Janssen Research \& Development, \\ A Division of Janssen Pharmaceutica NV, B-2340 Beerse, Belgium \\ ${ }^{\mathrm{b}}$ Laboratory for Translational Genetics, Department of Oncology, \\ University of Leuven, B-3000 Leuven, Belgium \\ ${ }^{c}$ Vesalius Research Center, VIB, B-3000 Leuven, Belgium \\ ${ }^{\mathrm{d}}$ Laboratory of Angiogenesis \& Neurovascular Link, B-3000 \\ Leuven, Belgium

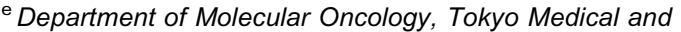 \\ Dental University, Tokyo, Japan \\ ${ }^{\mathrm{f}}$ Laboratory of Cell Biology and Histology, Department of \\ Veterinary Sciences, University of Antwerp, B-2020 \\ Antwerp, Belgium
}

\begin{abstract}
Besides its prominent role in angiogenesis, the vascular endothelial growth factor (VEGF) also exerts important protective effects on neurons. In particular, mice expressing reduced levels of VEGF suffer from late-onset motor neuron degeneration, whereas VEGF delivery significantly delays motor neuron death in ALS mouse models, at least partly through neuroprotective effects. Additionally, VEGF protects dorsal root ganglion (DRG) neurons against paclitaxel-induced neurotoxicity. Here, we demonstrate that VEGF also protects DRG neurons against hyperglycemiainduced neuronal stress as a model of diabetes-induced peripheral neuropathy. Specifically, VEGF decreased expression of the stress-related gene activating transcription factor 3 (ATF3) in DRG neurons isolated from streptozotocin-induced diabetic mice (ex vivo) and in isolated DRG neurons exposed to high glucose concentrations (in vitro). In vivo, local VEGF application also protected against paclitaxel- and diabetes-induced neuropathies without causing side effects. A small synthetic VEGF mimicking pentadecapeptide $(Q K)$ exerted similar effects on DRG cultures: the peptide reduced ATF3 expression in vitro and ex vivo in paclitaxel- and hyperglycemia-induced models of neuropathy to
\end{abstract}

\footnotetext{
${ }^{*}$ Corresponding author. Address: Department of Neuroscience, Janssen Research \& Development, A Division of Janssen Pharmaceutica NV, Turnhoutseweg 30, B-2340 Beerse, Belgium. Tel: +3214603214.

E-mail address: TMEERT@its.jnj.com (T. Meert).

+ These authors contributed equally to this work. Abbreviations: ALS, amyotrophic lateral sclerosis; ANOVA, analysis of variance; ATF3, activating transcription factor 3; AUC, area under the curve; DN, dominant negative; DRG, dorsal root ganglia; GDNF, glial cell-derived neurotrophic factor; PBS, phosphate-buffered saline; SEM, standard error of the mean; STZ, streptozotocin; VEGF, vascular endothelial growth factor; WT, wild-type; YFP, yellow-fluorescent protein
}

\begin{abstract}
a similar extent as the full-length recombinant VEGF protein. By using transgenic mice selectively overexpressing the VEGF receptor 2 in postnatal neurons, these neuroprotective effects were shown to be mediated through VEGF receptor 2. Overall, these results underscore the potential of VEGF and VEGF-derived peptides for the treatment of peripheral neuropathies. (C) 2013 IBRO. Published by Elsevier Ltd. All rights reserved.
\end{abstract}

Key words: peptide, peripheral neuropathy, VEGF.

\section{INTRODUCTION}

The vascular endothelial growth factor (VEGF) was originally discovered as a growth factor capable of increasing vascular permeability and endothelial cell proliferation. After binding to its VEGF receptor 1 (Flt1), VEGF receptor 2 (Flk1) and neuropilin (Nrp-1 and Nrp2), VEGF promotes endothelial cell proliferation, migration and survival (Leung et al., 1989; Ferrara et al., 2003). VEGF is also a potent endothelial cell survival factor during physiological and tumor angiogenesis (Benjamin and Keshet, 1997; Gerber et al., 1998). Furthermore VEGF is known as a vascular permeability factor, playing a significant role in inflammation and other pathological conditions (Senger et al., 1983; Dvorak et al., 1995). Evidence has been accumulating that VEGF, in addition to well-known effects on angiogenesis, exhibits more pluripotent activities, particularly in the nervous system.

Neurotrophic effects of VEGF were first described by Sondell et al., who reported that VEGF promotes axonal outgrowth of primary dorsal root ganglia (DRG) (Sondell et al., 1999). Whether VEGF also exerts such direct neuroprotective effects on sensory neurons in vivo is not known. Although VEGF therapy has already shown therapeutic potential in peripheral neuropathies caused by diabetes or chemotherapy, these effects were mainly attributed to its vessel- and perfusion-promoting effects, rather than to its direct neuroprotective properties (Schratzberger et al., 2001; Kirchmair et al., 2007). The most convincing evidence for in vivo neuroprotective effects of VEGF originates from studies in knock-in mice, in which a subtle deletion of the hypoxia-response element reduced expression levels of VEGF and caused adult-onset progressive degeneration of motor neurons, reminiscent of amyotrophic lateral sclerosis (ALS). Moreover, overexpression of VEGF or Flk1 in neurons, substantially delayed disease symptoms in models for ALS (Oosthuyse et al., 2001; Storkebaum et al., 2005). 
Meanwhile, VEGF was also found to be implicated in other neurological diseases, including recovery from stroke (Wang et al., 2009), Alzheimer's disease (Del Bo et al., 2009) and Parkinson's disease (Yasuhara et al., 2005). In most of these studies, however, it was unclear whether VEGF exerted this neuroprotection through direct neurotrophic or perfusion-promoting effects.

Recently, a VEGF-derived peptide was generated with similar biological properties and VEGF receptorbinding capacities as the full-length VEGF protein (D'Andrea et al., 2005; Ziaco et al., 2012). In several later studies, this peptide has been functionally and pharmacologically characterized as pro-angiogenic with positive effects on wound healing (Santulli et al., 2009; Finetti et al., 2012). Whether this VEGF-derived peptide also exerts neuroprotective activities has not been studied before.

In light of the emerging recognition of VEGF as a dual 'neuro-vascular' factor, we investigated whether VEGF, in addition to its well-established vascular effects, exerts direct neuroprotective effects on sensory neurons during diabetic- and chemotherapy-induced neuropathies. Hyperglycemia-induced neuronal stress levels were measured to evaluate in vitro and ex vivo protective effects of VEGF. The therapeutic potential of VEGF was tested in vivo in streptozotocin (STZ)-induced diabetic and subplantar paclitaxel neuropathy models. Transgenic mice and the anti-Flk1 antibody (DC101) were used to study whether the effects of VEGF were mediated through its Flk1 receptor. Finally, also the therapeutic potential of a recently generated VEGFderived peptide was evaluated in these different models.

\section{EXPERIMENTAL PROCEDURES}

\section{Animals}

Male adult Sprague Dawley rats (Harlan, The Netherlands) were used for all rat based experiments. Male C57BL/6JCrl (Charles River, Belgium) or FVB (Harlan, The Netherlands) were used for mouse-based experiments. Transgenic mice: Thy: $\mathrm{Flk} 1^{\mathrm{WT}}$ and Thy:Flk $1^{\mathrm{DN}}$ mice expressing a wild-type (WT) or truncated murine Flk1 transgene in postnatal neurons, were generated by pronuclear injection of a mouse Thy1.2 expression cassette. These mice were further intercrossed with Thy:YFP mice to obtain Thy:YFP $\times$ Thy:FIk1 ${ }^{\text {WT }}$ mice. Knock-in mice expressing a tyrosine kinase-dead Flt1 receptor (Flt-TK ${ }^{-1-}$ mice) were backcrossed to an FVB background. Before starting the experiment, all animals were habituated to handling and test environments. Rats and mice were housed in conventional facilities with a 12-h light/dark cycle with access to food ad libitum. All experiments were approved by the local ethical committee.

\section{Subplantar paclitaxel model}

Paclitaxel $\left(\right.$ Taxol $^{\circledR}$, Bristol Myers Squibb as $6 \mathrm{mg} / \mathrm{ml}$ in Cremaphor EL solution) was formulated in Cremaphor/ Ethanol $(150 \mu \mathrm{g}$ per dose, $50 \mu \mathrm{l})$ for rats or in saline (75 $\mu \mathrm{g}$ per dose, $25 \mu \mathrm{l})$ for mice, and was injected directly into the left hind paw for four consecutive days. The needle was introduced under the skin between the 2nd and 3rd toes and gently slid toward the heel. One hour before each subplantar paclitaxel injection, recombinant rat VEGFA or glial cell-derived neurotrophic factor (GDNF) $(50 \mu \mathrm{g}$, PeproTech EC, London) diluted in phosphate-buffered saline (PBS), was subplantarily delivered, $1 \mathrm{~h}$ before paclitaxel, in the same hind paw in a volume of $10 \mu \mathrm{l}$ for mice or $50 \mu \mathrm{l}$ for rats. PBS was used as a control. All animals were pinpricked before subplantar injections. Paw thickness (IITC Inc. Life Science, Woodland Hills, CA, USA) was measured $24 \mathrm{~h}$ after each VEGF injection, before paclitaxel injections.

\section{Diabetes rat and mouse models}

Seven-week-old male FVB mice (Harlan, The Netherlands) and male Sprague-Dawley rats (Harlan, France) were fed a standard diet and had access to water ad libitum. Diabetes was induced by a single intraperitoneal injection of STZ $(180 \mathrm{mg} / \mathrm{kg}$ for mice and $65 \mathrm{mpk}$ for rats) to animals that were fasted overnight (starvation for 20-24 h). To measure glucose levels, blood samples were taken from the tail vein 7 days after STZ injection. Mice and rats with a blood glucose level above $250 \mathrm{mg} / \mathrm{dl}$ were considered diabetic and used for further experiments. Control animals were injected with a buffer solution.

\section{Behavioral analyses}

Pinprick test. All animals were allowed to habituate for $30 \mathrm{~min}$ in individual testing chambers on a metal mesh floor. A bend 22-gauge needle for rats and a bend $1 \mathrm{ml}$ syringe for mice were gently applied to the plantar surface of the hind paw without breaking the skin. The needle was applied to alternating feet and $30 \mathrm{~s}$ was allowed to elapse between applications to the same foot. A response (scored as 0 ) was defined as lifting, shaking or licking the hind paw. No response was scored as 1 . Three scores of each hind paw were taken for each animal.

Von Frey test. The electronic Von Frey test was used to evaluate mechanical (tactile) allodynia. All animals were allowed to habituate for $30 \mathrm{~min}$ in individual testing chambers on a metal mesh floor. Gradually increased pressure was applied with a mechanical Von Frey probe (Senselab ${ }^{\circledR}$ Somedic, Hörby, Sweden) positioned perpendicularly into the mid-plantar surface. The stimulus was continued until the hind paw was withdrawn or slowly elevated (defining a withdrawal threshold). Peak forces were recorded in grams. Three measurements were taken for each hind paw and averaged.

Paw pressure test. Mechanical hyperalgesia was quantified with an Analgesy meter (Ugo-Basile, Comerio, Italy). An increasing pressure was applied with a cone-shaped plunger on the dorsal area of the hind 
paw. The nociceptive threshold was defined as the force, in grams, at which the rat attempted to withdraw its paw, vocalized or struggled. The cut-off force was set at $250 \mathrm{~g}$.

Hargreaves' test (paw flick). Animals were allowed to habituate in the clear plastic testing chambers for $30 \mathrm{~min}$. A radiant heat produced by a light source from underneath (Plantar test ${ }^{\circledR}$, IITC Life Science Inc.) was administered to the plantar surface of the hind paw, with an intensity such that no tissue damage occurred throughout the duration of the cut-off latency of $20 \mathrm{~s}$. The heat stimulus was given until the animal withdrew its paw or until the cut-off time was reached. Withdrawal was defined as lifting, licking or flinching of the paw. For each animal three measurements of each hind paw were taken with a 5-min interval between measurements.

\section{In vivo imaging}

To visualize blood vessel perfusion, mice were anesthetized with isoflurane after IV injection of fluorescent dextran (Oregon Green, Invitrogen molecular probes, $70 \mathrm{kDa}$ ). The plantar surface of the hind paw was scanned with the CellVizio ${ }^{\circledR}$ (Mauna Kea Technologies, Paris, France) probe. Images were quantified using KS300 image analysis software from Zeiss. Peripheral sensory nerves in the hind footpad of Thy:YFP mice were imaged with a Zeiss CLSM510 NLO META mounted on an AxioVert $200 \mathrm{M}$ inverted microscope (Zeiss, Sliedrecht, The Netherlands) at $35^{\circ} \mathrm{C}$ and normal oxygen levels. Multiphoton imaging of peripheral nerves was performed using 920-nm pulsed mode-locked laser emission from a tunable Ti:Sapphire Chameleon laser (Coherent, The Netherlands). Imaging was performed with the minimal necessary laser power. Stacks of frame-averaged (five frames) confocal optical slices were collected digitally. Two-dimensional reconstructions of image data were prepared using the LSM software package and images were quantified using KS300 image analysis software from Zeiss.

\section{Histology}

To stain the epidermis of the footpads, epidermal and dermal layers were dissociated (Tschachler et al., 2004). After removing the hypodermis, skin tissue was incubated with $2.4 \mathrm{U} / \mathrm{ml}$ Dispase. After $45 \mathrm{~min}$ at $37^{\circ} \mathrm{C}$, epidermis was removed from the underlying dermis with watchmaker's forceps. The surface size of each dermal whole mount preparation was approximately $50 \mathrm{~mm}^{2}$. Whole preparations were then fixed for $2 \mathrm{~h}$ with Zamboni's fixative $(0.2 \%$ saturated picric acid, $4 \%$ paraformaldehyde; $0.1 \mathrm{M}$ phosphate buffer; $\mathrm{pH} 7.4$ ) and rinsed in PBS. Epidermis tissues were used in immunohistochemical stainings with antibodies directed against PgP9.5 (Chemicon, Temecula, CA, USA), Flk1 (Santa Cruz Biotechnology Inc; CA, USA) and subsequent incubation with Alexa 488 (Molecular Probes, Life Technologies, Gent, Belgium) or FITC and Fab-Cy3 (Jackson Immunoresearch). AF1 (Citifluor) was used to mount footpads.

\section{Isolation and treatment of dorsal root ganglion neurons}

DRG's (all levels, unless explicitly specified) were dissected from the spinal column and collected in PBS containing $1 \mathrm{~g} / \mathrm{l}$ glucose. Ganglia were then enzymatically dissociated by incubation in medium containing $0.5 \%$ collagenase followed by $0.25 \%$ trypsin. Subsequently, ganglia were mechanically dissociated into single cells. The cell suspension was placed in a Petri dish coated with fetal calf serum (FCS) for 90 min at $37^{\circ} \mathrm{C}$. DRG neurons were plated in poly-L-lysine coated 96-well plates in Neurobasal medium supplemented with B27 (Gibco, Life Technologies, Gent, Belgium). VEGF-A or the monoclonal anti-FIk1 antibody (DC101) was added to the culture medium $4 \mathrm{~h}$ prior to glucose addition. In all experiments, neurons were cultured for at least $24 \mathrm{~h}$ after the addition of glucose.

\section{Immunocytochemistry}

DRG neurons were fixed using $0.5 \%$ Triton X100 (Sigma, Seelze, Germany) and $0.5 \%$ glutaraldehyde dissolved in PHEM buffer (buffer containing PIPES, double Hanks, EGTA and $\mathrm{MgCl} 2$ ). Cells were permeabilized with $0.5 \%$ Triton $X 100$ and incubated in $1 \mathrm{mg} / \mathrm{ml} \mathrm{NaBH}_{4}$ in PHEM. Primary antibodies used are polyclonal anti-activating transcription factor 3 (ATF3) (Santa Cruz Biotechnology Inc; CA, USA; 1:800) and monoclonal anti-neurofilament SMI32 (Sternberger Monoclonals Incorporated, Covance; Princeton, New Jersey, USA 1:1000). Subsequently, cells were incubated with Alexa 488 and Alexa 555 secondary antibodies (Invitrogen, Molecular Probes, Life Technologies, Gent, Belgium). DAPI (4',6diamidino-2-phenylindole, Sigma, Seelze, Germany) was added for $5 \mathrm{~min}$ as a nuclear counterstain. The percentage of ATF3-positive neurons was determined using fluorescence microscopy and by analyzing $>100$ cells per well. Only SMI-positive cells were considered. Data were normalized to the controls of the respective experiments and expressed as relative \%ATF positive DRG neurons. Under control conditions, about $30 \%$ of DRG neurons are ATF-positive due to the isolation procedure.

\section{Mitochondrial membrane potential}

Mouse DRG neurons were cultured overnight in 96-well plates. The next day, neurons were loaded for $20 \mathrm{~min}$ with $2 \mu \mathrm{M}$ JC-1 (Invitrogen, Life Technologies, Gent, Belgium) in experimental medium. JC-1 is a lipophilic cationic dye from which the spectral characteristics depend on the mitochondrial membrane potential. In depolarized mitochondria $\mathrm{JC}-1$ exists as monomers in the cytoplasm which emit a green fluorescence. In hyperpolarized mitochondria $\mathrm{JC}-1$ accumulates in the mitochondrial membrane and forms J-aggregates which emit a red fluorescence. After washing, fluorescence was measured with a Zeiss LSM510 confocal microscope at two different wavelengths with excitation:emission of 488:527 for green and 543:590 for red. For the in vitro experiments 15 images were made 
with an interval of 15 seconds. After three images, glucose was added and FCCP (Trifluorocarbonylcyanide Phenylhydrazone) (Sigma, Seelze, Germany), as a positive control for depolarization, was added after image 12. For the ex vivo experiments 10 images were made with FCCP addition after image 6. Green to red ratio's were calculated and normalized to FCCP-treated cells.

\section{Statistics}

All data are shown as the mean \pm standard error of the mean (SEM). To calculate differences between two groups, unpaired Student's $t$-tests were performed considering equal variances. For more than two groups one-way analysis of variance (ANOVA) was used. Curves of the paclitaxel-induced neuropathy experiments show mean \pm SEM, overall differences between curves were obtained by calculating the area under the curve (AUC) per animal and by calculating the statistical difference between these AUC values using a standard Student's $t$-test. A Chi-Square test was used to calculate statistical differences on individual days. For the Von Frey measurements, overall differences between groups were calculated using the repeated measurement ANOVA test. Differences for the separate days were calculated using a standard Student's $t$-test.

\section{RESULTS}

\section{VEGF protects against hyperglycemia-induced neuronal deficits}

To study the therapeutic potential of VEGF in diabetesinduced peripheral neuropathy in vitro and ex vivo, we first quantified ATF3 expression levels, representing neuronal stress responses, in hyperglycemic conditions (Tsujino et al., 2000; Shortland et al., 2006; Peeraer et al., 2011). Expression of the stress-related gene ATF3 is one of the earliest events reported after injury. Following this approach, neuronal injury could be detected long before the occurrence of other damage like apoptosis.

We previously showed that high glucose concentrations $(>60 \mathrm{mM})$ induce increased ATF3 expression levels in vitro, which can be easily quantified using immunocytochemistry (Peeraer et al., 2011). To assess the effect of VEGF on neuronal stress, glucosechallenged dorsal root ganglion (DRG) cultures were treated for $24 \mathrm{~h}$ with different concentrations of VEGF $(0.01-10 \mathrm{ng} / \mathrm{ml})$. A dose-dependent decrease in glucose-induced ATF3 expression (Fig. 1A) could be observed with increasing VEGF concentrations. To evaluate the effect of VEGF on the neuronal stress response in an ex vivo model for diabetic peripheral neuropathies, DRGs were isolated from diabetic mice 6 weeks after STZ injection, i.e. the time point where all mice had developed diabetic neuropathy (data not shown). DRG neurons were cultured and treated for $24 \mathrm{~h}$ with VEGF concentrations ranging from 0.1 to $25 \mathrm{ng} / \mathrm{ml}$. Similar to the results in the in vitro glucose model VEGF treatment dose-dependently decreased diabetes-induced ATF3 expression (Fig. 1B).
To confirm the protective and therapeutic potential of VEGF, we assessed whether VEGF administration also protected DRG neurons against hyperglycemia-induced mitochondrial membrane depolarization, which is one of the earliest markers of apoptosis and represents another hallmark of diabetic neuropathy (Srinivasan et al., 2000). In vitro, administration of glucose to control DRG cultures caused a significant increase in membrane depolarization, which could be effectively inhibited when DRG cultures were pretreated with VEGF for $4 \mathrm{~h}$ (Fig. 1C). These effects were confirmed ex vivo. DRG neurons isolated from 6-week-old diabetic mice also displayed an increased membrane depolarization, which was significantly reduced by a 4-h VEGF treatment before measuring the $\mathrm{JC}-1$ ratio (Fig. 1D). Notably, the increased mitochondrial membrane depolarization did not induce increased cell death in vitro or ex vivo (not shown). Nevertheless, VEGF increased the viability of the adult DRG cultures over time under normal culturing conditions (data not shown). These results indicate a protective effect of VEGF on diabetes-induced disruption of mitochondrial function and confirm a protective effect of VEGF on diabetes-associated neuronal deficits in DRG cultures.

\section{Subplantar VEGF protects against diabetes-induced neuropathy in vivo}

Chronic hyperglycemia in diabetes causes a variety of somatosensory deficits, including a reduced cutaneous innervation in the hind limb skin (Hirai et al., 2000) (Lauria et al., 2005). Although the mechanisms behind this axonal defect are not well understood, a deficit in neurotrophic support to stimulate axonal regeneration of terminal axons has been proposed (Apfel, 1999; Christianson et al., 2003). To assess whether the subplantar delivery of VEGF exerts beneficial effects in a diabetes neuropathy model, rats were intraperitoneally injected with STZ $(65 \mathrm{mg} / \mathrm{kg}$ in a volume of $1 \mathrm{ml} / 100 \mathrm{~g}$ rat) and diabetic neuropathy in the hind paw was subsequently monitored using the paw pressure test (Fig. 2A). Three weeks after STZ injection, rats with hypersensitivity toward mechanical pressure were randomized into two groups and were subplantarily administered either VEGF $(10 \mu \mathrm{g})$ or solvent for three consecutive days. Diabetic rats treated with VEGF showed a better withdrawal response compared to PBStreated rats (Fig. 2A).

To evaluate the in vivo effect of VEGF on neuronal stress, lumbar DRGs (L4-L6) from VEGF- and PBSinjected rats were dissected and cultured for ATF3 quantifications. DRG neurons (left, injected side) dissected from rats receiving subplantar VEGF injections had significantly less neuronal stress than DRG neurons of rats injected with PBS (Fig. 2B). Notably, also DRG neurons (right side) coupled to the non-injected paw (right paw) displayed lower ATF3 levels when rats were injected (left paw) with VEGF. These results suggest that the neuroprotective effects of VEGF are transmitted between DRGs, although without significantly improving nociceptive behavior in the noninjected paw (data not shown). Only a non-significant 
A

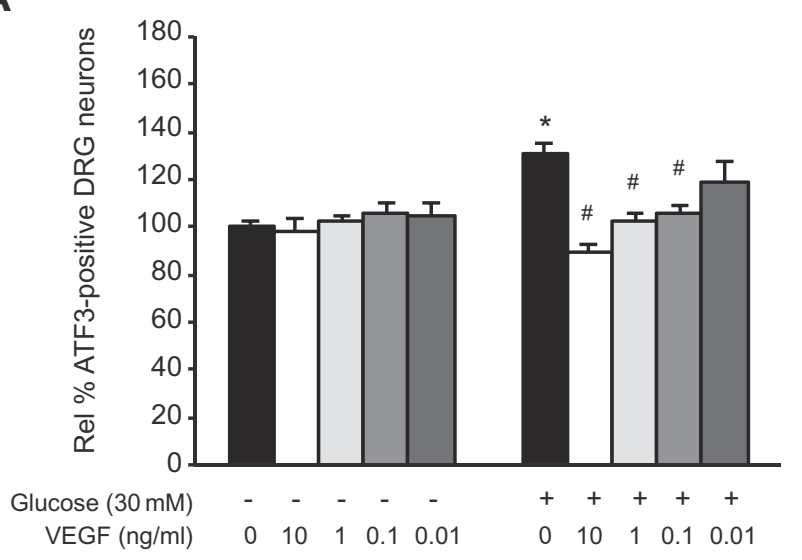

C

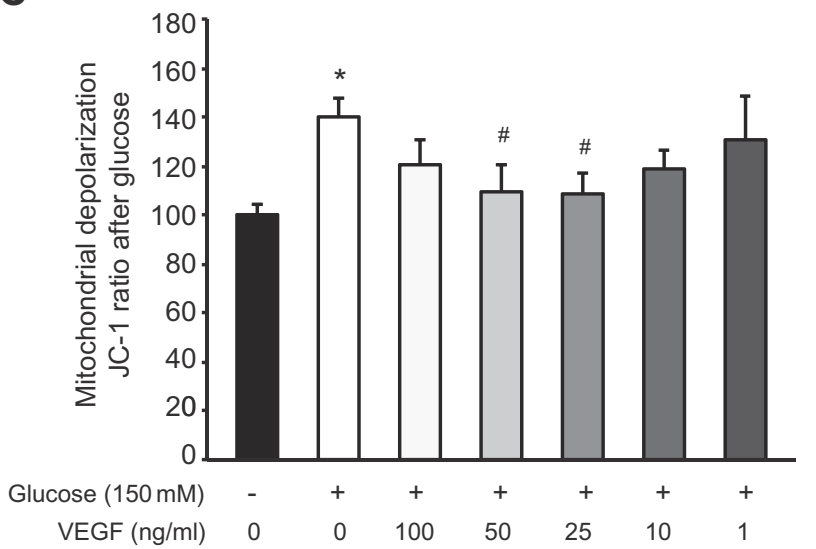

B

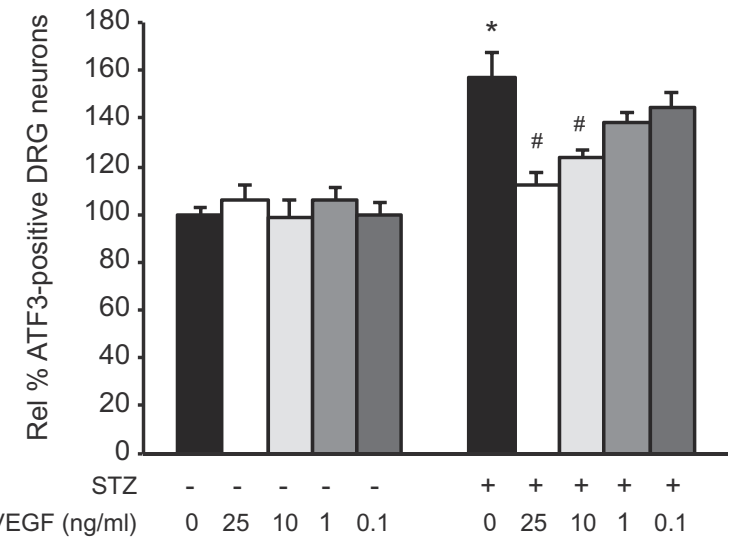

D

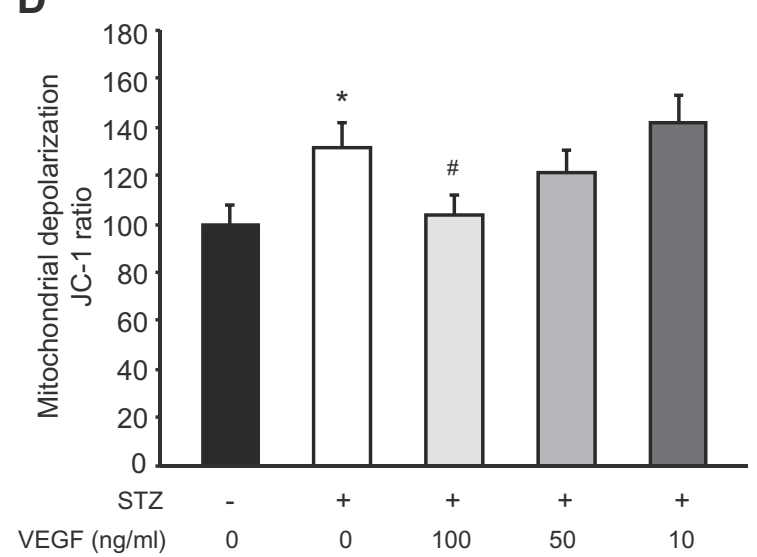

Fig. 1. VEGF protects against hyperglycemia-induced neuronal deficits in vitro and ex vivo: (A) VEGF protects against glucose-induced neuronal stress (ATF3 increase). Addition of VEGF concentrations between 0.01 and $10 \mathrm{ng} / \mathrm{ml}$ dose-dependently decreases glucose-induced ATF3 expression ( $n=6$ wells from three rats). ${ }^{*} P<0.05$ versus non-treated control cultures and ${ }^{\#} P<0.05$ versus glucose-challenged DRG cultures. (B) VEGF protects against diabetes-induced neuronal stress. Addition of VEGF concentrations between 0.1 and 25 ng/ml decreases ATF3 expression in DRG neurons isolated from diabetic mice in a dose-dependent way ( $n=6$ wells from three mice). ${ }^{*}<0.05$ versus control cultures isolated from control mice and ${ }^{\#} P<0.05$ versus non-treated cultures isolated from diabetic mice. (C) VEGF protects against high glucose-induced mitochondrial membrane depolarization. Treatment with VEGF concentrations between 1 and $100 \mathrm{ng} / \mathrm{ml}$ causes a decrease in high glucoseinduced mitochondrial depolarization ( $n=12$ wells from six mice). ${ }^{*} P<0.05$ versus non-treated control cultures. ${ }^{\#} P<0.05$ versus glucosechallenged DRG cultures. (D) VEGF protects against diabetes-induced mitochondrial depolarization. Treatment of DRG neurons isolated from diabetic mice with doses between 100 and $10 \mathrm{ng} / \mathrm{ml}$ VEGF causes a decrease in diabetes-induced mitochondrial depolarization being significant at a dose of $100 \mathrm{ng} / \mathrm{ml}$ VEGF ( $n=15$ wells from five mice). ${ }^{*} P<0.05$ versus control cultures and ${ }^{\#} P<0.05$ versus non-treated cultures isolated from diabetic mice.

trend was observed ( $P=0.1$, data not shown). Possibly the duration or dose of VEGF treatment or the amount of animals in our experimental setup was insufficient to show significant effects in the contralateral foot pad.

To test the safety profile of subplantarily delivered VEGF, we injected VEGF subplantarily in the left paw from rats during four consecutive days ( $n=5$ rats for each treatment group) and assessed whether these rats developed mechanical allodynia or hyperalgesia (by using a Von Frey aesthesiometer and the paw pressure test; Fig. 2C, D) or thermal hyperalgesia (using the paw flick test; Fig. 2E). Each test was performed daily. No overall significant differences were detectable suggesting that VEGF delivery is well tolerated.

Overall, these results confirm the therapeutic effect of VEGF in vivo, in a model for diabetic neuropathy without causing side effects.

\section{VEGF protects against hyperglycemia-induced neuronal stress through its Flk1 receptor}

To test whether the neuroprotective effects of VEGF are mediated through its main Flk1 receptor, we used a monoclonal rat anti-mouse anti-Flk1 antibody (DC101) (Tessler et al., 1994) in combination with VEGF, and evaluated hyperglycemia-induced neuronal stress responses in DRG cultures. As previously shown, VEGF reduced ATF3 expression levels in hyperglycemic cultures in vitro, which was not the case when these cultures were pretreated with DC101 $(10 \mu \mathrm{g} / \mathrm{ml})$ (Fig. 3A). Similarly, VEGF also protected DRG neurons dissected from diabetic mice against neuronal stress, which was inhibited when these cultures were pretreated with the anti-Flk1 monoclonal antibody (Fig. 3B). Both in vitro and ex vivo results indicate an 
important role for Flk1 in these VEGF-mediated neuroprotective effects.

\section{The Flk1 receptor is expressed in the skin dermis}

Previous reports showed that Flk1 is expressed in whole DRGs and DRG cultures (Sondell et al., 2000; Verheyen et al., 2012). To confirm that Flk1 is also present in sensory neurons and nerves of the footpad, and is thus capable of transmitting the neuroprotective effects of VEGF in vivo, we assessed the expression profile of Flk1 in the terminal axons of intra-dermal sensory nerves of the footpad.

Double immunohistochemistry for Flk1 and the panneuronal marker PGP9.5 on skin flap preparations revealed that Flk1 was indeed expressed in nerve endings (Fig. 3C-E). Together, these data indicate that the molecular players necessary for VEGF to exert its direct neuroprotective effects are present in the sensory nervous system.

\section{VEGF protects against paclitaxel-induced neuropathy in vivo}

To confirm the direct protective effect of VEGF in the sensory nervous system in vivo, we used another model for peripheral neuropathy, induced by paclitaxel. Although VEGF protects DRG neurons in vitro against paclitaxel-induced toxic effects (Verheyen et al., 2012), direct neuroprotective effects of VEGF in paclitaxelinduced neuropathy in vivo have not been shown before.

Since sensory nerve function can easily be assessed at the functional level in the plantar dermis of the hind paw, this location was used to study the neuroprotective effects of VEGF in vivo. Rats were subplantarily challenged with paclitaxel during four consecutive days (Wilson et al., 2006) causing retrograde degeneration of
A

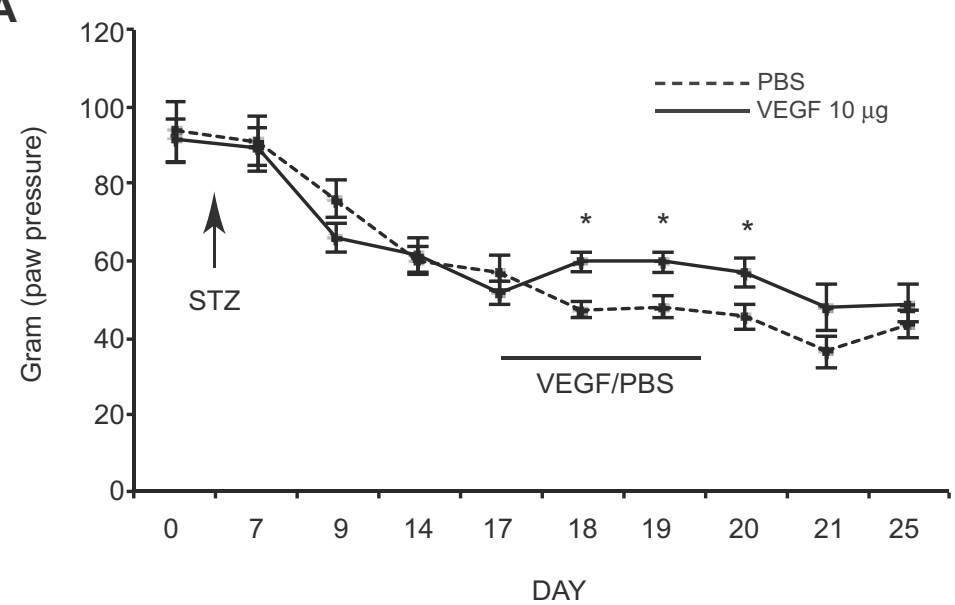

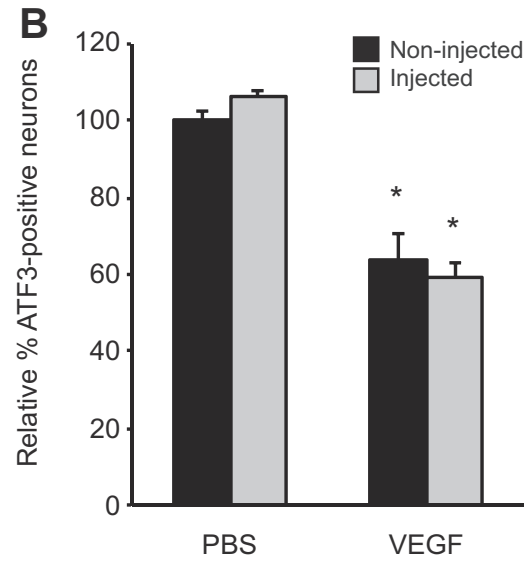

E

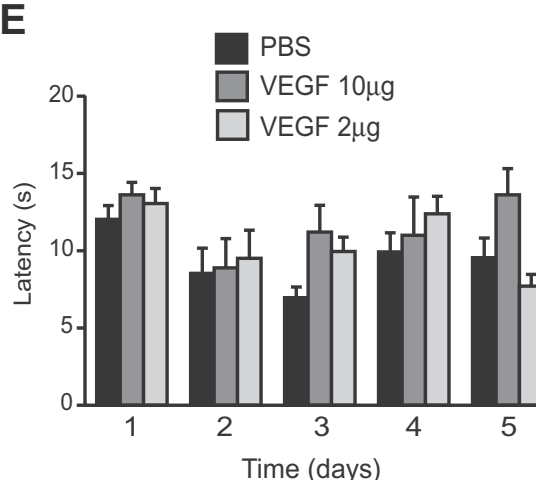

Fig. 2. Subplantar VEGF protects against diabetic neuropathy in vivo. (A) VEGF ameliorates diabetes-induced mechanical hyperalgesia. Intraperitoneal injection of STZ in rats causes diabetic neuropathy as monitored by the paw pressure test for mechanical hyperalgesia. Eighteen days after STZ injection, $10 \mu \mathrm{g}$ VEGF or PBS ( $n=15$ versus 14 rats, respectively) is subplantarily injected for three consecutive days. Diabetic rats treated with VEGF almost immediately display an improved response, they display an average withdrawal response of $56.6 \pm 2.8 \mathrm{~g}$ compared to $44.4 \pm 2.7 \mathrm{~g}$ in control rats over the 3 days of VEGF delivery $(P=0.026) .{ }^{*} P<0.05$. (B) Subplantar VEGF treatment in diabetic rats reduces neuronal stress in vivo. DRG cultures (left side) prepared from diabetic rats subplantarily treated with VEGF (10 $\mu$ g) in their left paw have less neuronal stress than PBS-treated (left paw) diabetic rats $(P<0.05)$. Notably, the protective effect of VEGF is transmitted to DRG neurons of the non-injected right paw ( $P=\mathrm{NS}$ for left injected versus right non-injected paw). ${ }^{*} P<0.05$ versus PBS-treated rats. (C-E) To test the safety profile of subplantarily delivered VEGF, we injected 2 and $10 \mu \mathrm{g} / \mathrm{rat} /$ day VEGF in the left paw from rats during four consecutive days $(n=5$ rats for each treatment group). We then tested whether these rats developed mechanical allodynia or hyperalgesia (by using a Von Frey aesthesiometer and the paw pressure test; $A$ and $B$ ) or thermal hyperalgesia (using the paw flick test; $C$ ). Each test was performed daily. An overall statistical difference between the two VEGF groups and the solvent-treated group was assessed using ANOVA repeated measurement analysis. No overall significant differences were detectable $(P=0.45$ for Von Frey test; $P=0.75$ for paw pressure test and $P=0.24$ for heat hyperalgesia test). 
intra-epidermal nerve fibers and the development of a progressive sensory deficit, represented by numbness in patients (Rowinsky, 1993). The induced loss of sensitivity could be reliably assessed with the pinprick test and was reversible, since rats completely recovered from this deficit within a few days after halting paclitaxel injections. To assess the effect of VEGF in this model, recombinant rat VEGF (2 and $10 \mu \mathrm{g} / \mathrm{rat} /$ day) was subplantarily delivered $1 \mathrm{~h}$ prior to each paclitaxel injection. When monitoring the sensory deficit, we found that VEGF dose-dependently reduced the development of the axonopathy (Fig. 4A). Furthermore, rats treated with the high dose of VEGF also recovered faster after the last paclitaxel injection. Interestingly, the high dose of VEGF had a comparable effect as to that of GDNF, a neurotrophin with well-established neurotrophic activities in the peripheral nervous system. In addition, we assessed whether subplantar VEGF increased edema by determining the paw thickness (IITC Life Science Inc.) daily before VEGF/PBS and paclitaxel injections (Fig. 4B). No significant differences in paw volume could be detected between PBS- and VEGF-treated groups.

Additionally, the in vivo protective effect of VEGF was confirmed in a mouse subplantar paclitaxel model (data not shown). To visualize the neuroprotective effects of VEGF in vivo, mice expressing the yellow-fluorescent protein (YFP) under control of the neuronal Thy1.2 promoter (Thy:YFP mice) were injected subplantarily with paclitaxel and VEGF or PBS followed by in vivo imaging of YFP + sensory axons in the footpad. Since the degree of retrograde axon degeneration correlates with the pinprick scores, these scores can be used to quantify the sensory deficit in the mouse (Dhondt et al., 2011). Thy:YFP mice treated with subplantar VEGF displayed less retrograde degeneration than PBStreated mice (Fig. 4C). Additionally, tail vein injection
A

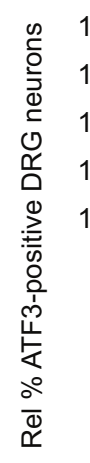

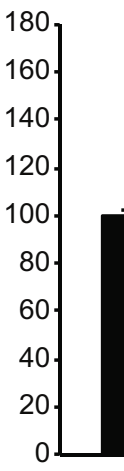

Glucose (30 mM) $\operatorname{VEGF}(10 \mathrm{ng} / \mathrm{ml})$ DC101 $(10 \mu \mathrm{g} / \mathrm{ml})$
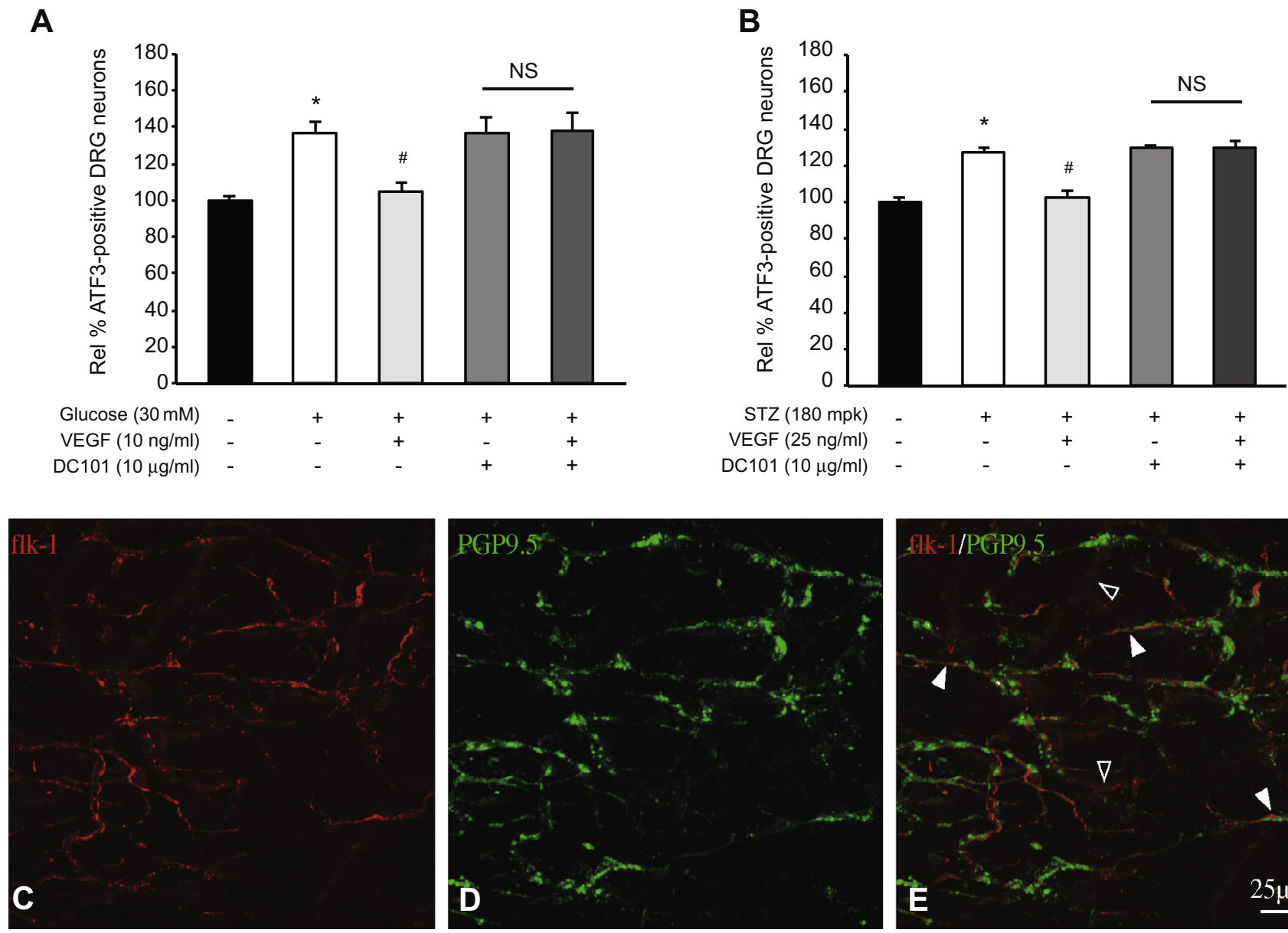

Fig. 3. Flk1 mediates the therapeutic effects of VEGF on diabetic neuropathy. (A) DC101, a monoclonal rat anti-mouse Flk1 neutralizing antibody, inhibits the neuroprotective properties of VEGF on cultured DRG neurons. VEGF (10 ng/ml) reduces glucose-induced ATF3 expression, whereas no reduced expression is seen when cultures are pretreated with DC101 $\left(10 \mu \mathrm{g} / \mathrm{ml} ; n=6\right.$ wells from three rats). ${ }^{*} P<0.05$ versus control cultures and ${ }^{\#} P<0.05$ versus glucose-challenged DRG cultures. (B) DC101 inhibits the neuroprotective effects of VEGF on diabetes-induced neuronal stress. VEGF $(25 \mathrm{ng} / \mathrm{ml})$ reduces glucose-induced ATF3 expression, but not so when combined with DC101 $(10 \mu \mathrm{g} / \mathrm{ml} ; n=6 \mathrm{wells}$ from three mice). ${ }^{*} P<0.05$ versus control cultures and ${ }^{\#} P<0.05$ versus DRG cultures isolated from diabetic mice. (C-E) Flk1 is expressed in the foot pad skin. Immunohistochemical double staining for Flk1 and protein gene product 9.5 (PGP9.5) was performed on a dermal whole-mount preparation of a wild-type mouse. Confocal imaging reveals Flk1-immunoreactive structures (red) in the dermis of the skin (C). A widespread network of nerve fibers is observed in the dermis (same region as in A) as shown by PGP9.5 immunostaining (D). Combined imaging (E) confirms the expression of Flk1 on intra-dermal PGP9.5-positive nerve fibers (arrowheads). Note that other structures, reminiscent of blood vessels, also exhibit weak immunoreactivity for Flk1 (open arrowheads). 
with a fluorescent dye, followed by imaging of the footpad vasculature, revealed that vessel perfusion was reduced after subplantar paclitaxel, but not so when mice had received subplantar VEGF in advance (Fig. 4D). Thus, in this model of retrograde degeneration of sensory neurons, VEGF protects nervous and vascular systems, which are both affected by high doses of paclitaxel.

\section{Flk1 mediates the neuroprotective effects of VEGF on paclitaxel-induced neuropathy in vivo}

We next assessed whether the Flk1 receptor could mediate the neuroprotective effects of VEGF in this subplantar paclitaxel model. To this end, transgenic mouse strains with overexpression of neuronal WT (Thy:Flk1 ${ }^{\text {WT }}$ mice) or dominant negative (DN) Flk1
(Thy: $\mathrm{Flk} 1^{\mathrm{DN}}$ mice) were used. To underscore the in vivo relevance of Flk1 in DRG neurons, Thy:Flk $1^{\mathrm{WT}}$ and Thy:Flk1 ${ }^{\mathrm{DN}}$ mice were challenged with subplantar paclitaxel. We have previously shown that both mouse strains appeared healthy and fertile, and exhibited normal densities of nerves (PGP9.5+ axons) and perfused vessels in the skin of their paws (Verheyen et al., 2012). They also both responded normally in the pinprick assay. Upon challenge with paclitaxel, Thy:Flk1 ${ }^{W T}$ mice developed a much milder sensory deficit than WT mice (Fig. 5A), presumably because neuroprotective Flk1 signaling in response to endogenous VEGF was enhanced. After intercrossing Thy:YFP mice with Thy:Flk1 ${ }^{\mathrm{WT}}$ mice, live imaging confirmed that there was less retrograde degeneration of Thy:YFP $\times$ Thy:Flk $1^{\mathrm{WT}}$ than of Thy:YFP axons
A
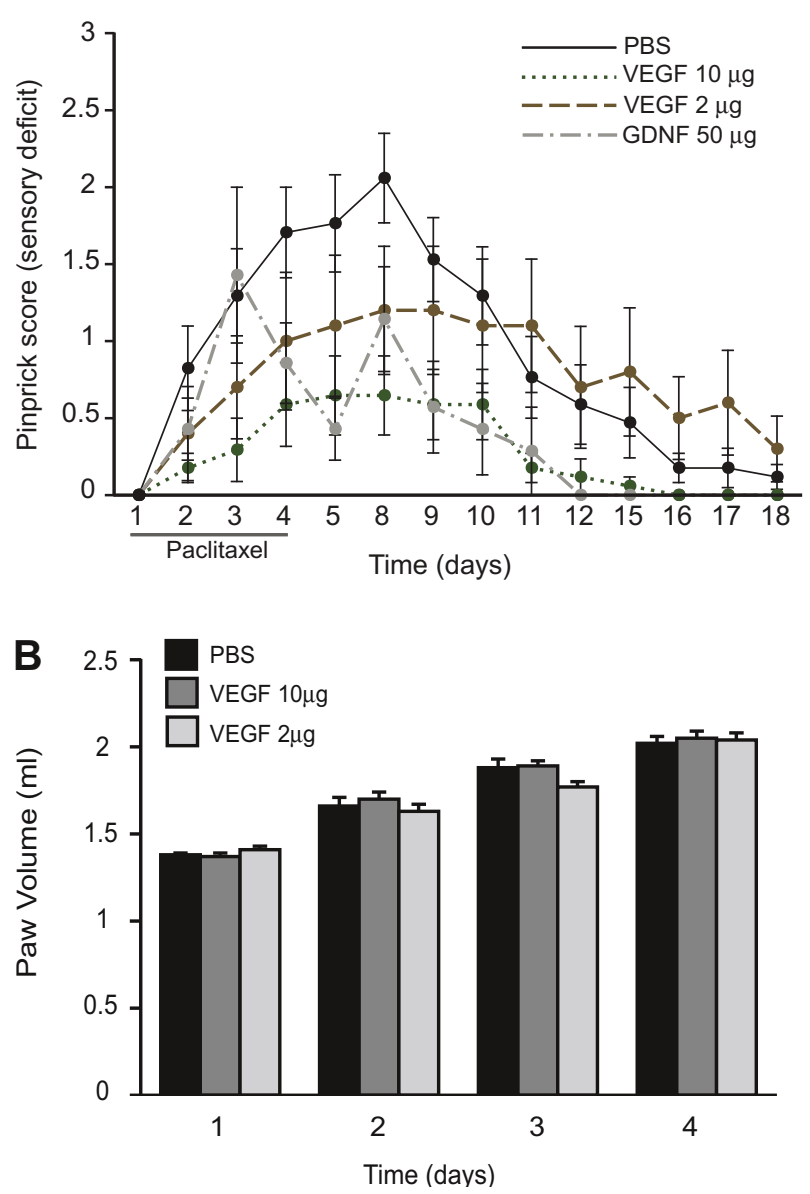

C
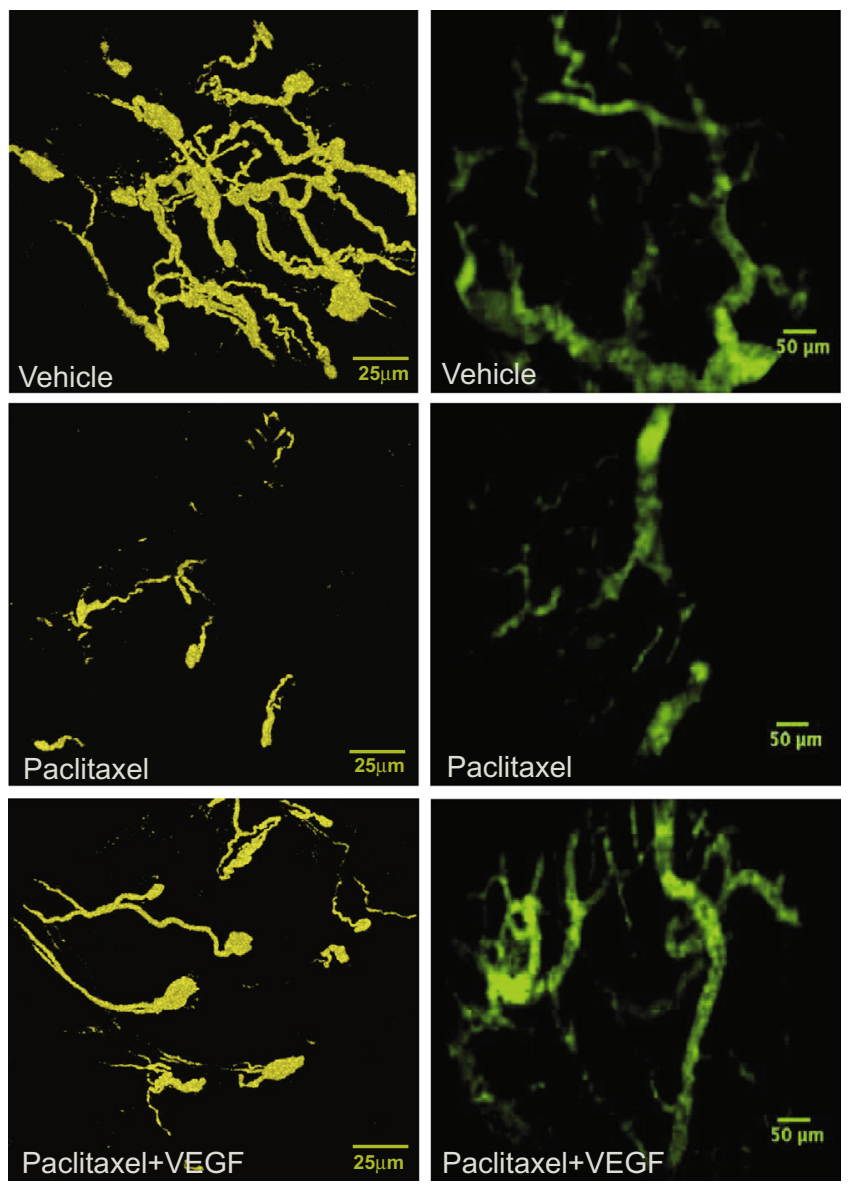

Fig. 4. VEGF exerts neuroprotective effects in paclitaxel-induced distal neuropathy: (A) subplantar delivery of recombinant VEGF protects against the retrograde degeneration of sensory axons $(P=0.6$ and 0.0021 for the low and high dose of VEGF versus PBS). Averaged pinprick scores are shown to visualize the sensory deficit in time. Seven days after the last paclitaxel injection, all VEGF-treated rats, but only $40 \%$ of control rats, react normally to a pinprick challenge $(P=0.003$ by Chi-square analysis). GDNF $(50 \mu \mathrm{g})$ exerts a similar therapeutic effect as VEGF $(10 \mu \mathrm{g}$; $P=0.61$ for VEGF versus GDNF groups, and $P=0.05$ for GDNF versus solvent-treated groups; $n>7$ per group). (B) In addition, we assessed whether subplantar VEGF increases paclitaxel-induced edema by determining the paw thickness (IITC Life Science Inc.) $24 \mathrm{~h}$ after each VEGF injection in combination with paclitaxel. No significant differences are detected. (C) Multiphoton imaging of YFP-positive sensory axons reveals that there is less axonal degeneration after paclitaxel administration in VEGF-treated mice than in PBS-treated Thy:YFP mice (YFP-positive area: $1.90 \pm 0.61 \%$ in VEGF-treated paclitaxel mice versus $0.46 \pm 0.18 \%$ in PBS-treated paclitaxel mice on the first day after halting paclitaxel injections; $n=12-11$; $P=0.042$ ). (D) CellVizio imaging of perfused vessel area in the footpad reveals that VEGF protects the vasculature against paclitaxel challenge (perfused vessel area: $17.18 \pm 3.83 \%$ in paclitaxel-injected mice treated with VEGF versus $8.81 \pm 1.46 \%$ in paclitaxel-injected mice treated with PBS on the first day after the last paclitaxel injection; $n>4$ per group; $P=0.031$ ). 
A

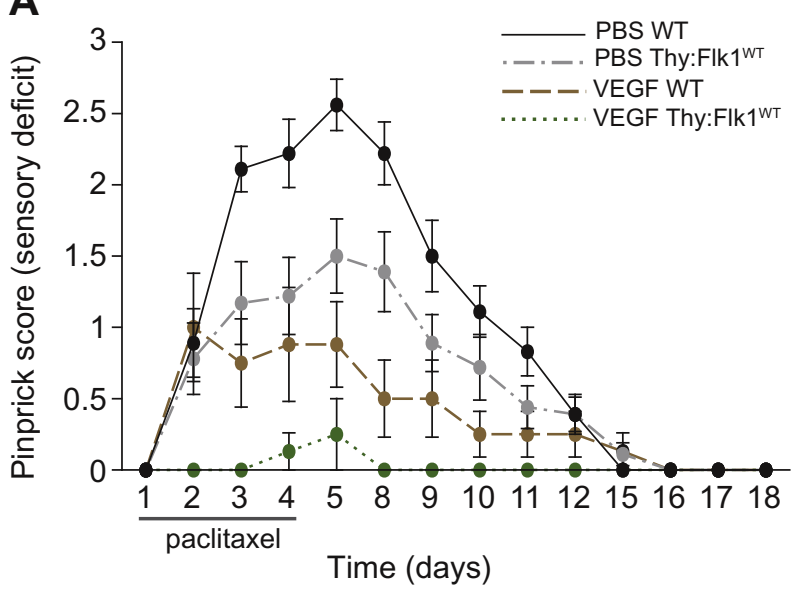

B

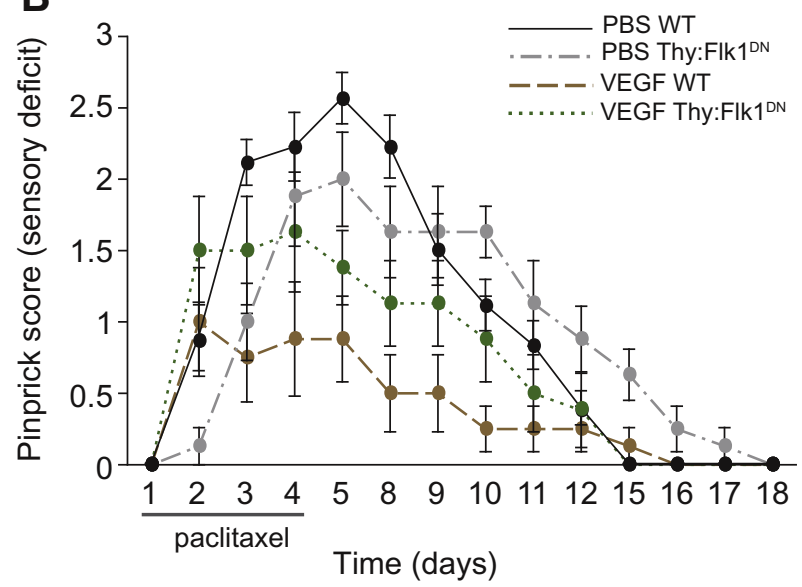

C

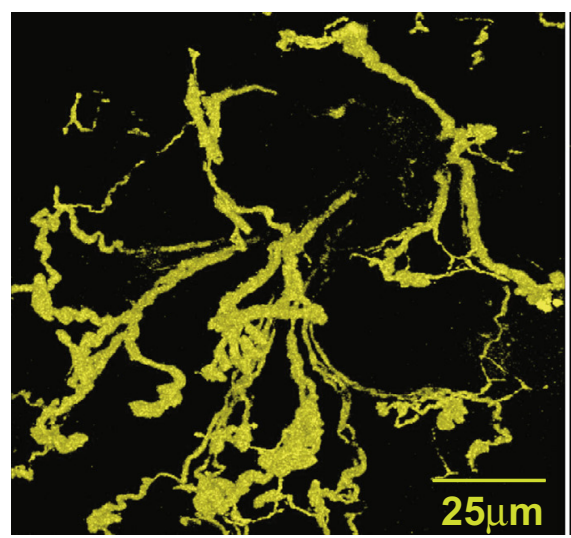

Thy:YFP/vehicle

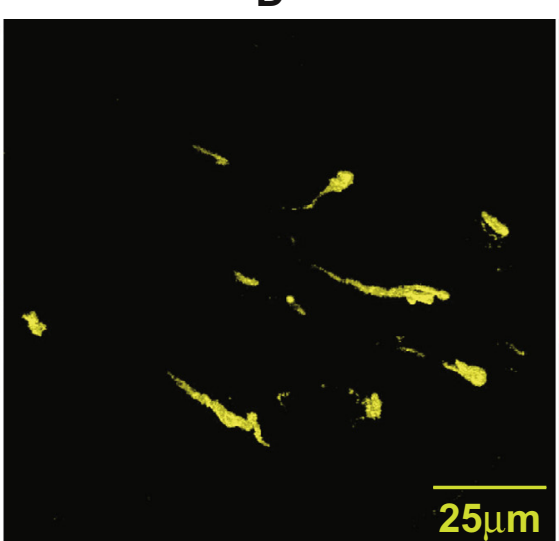

Thy:YFP/paclitaxel
E

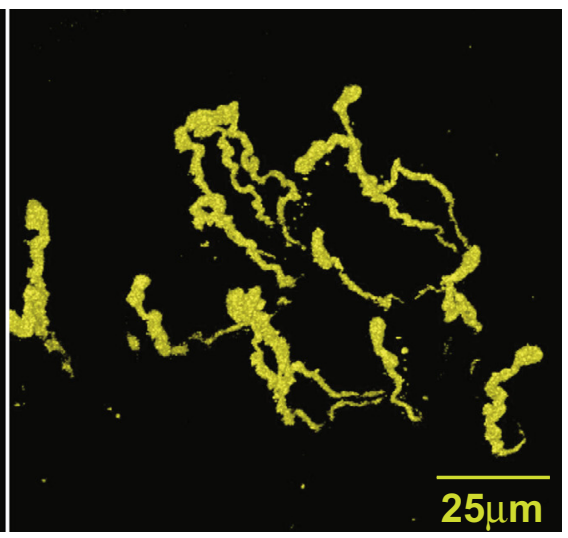

Thy:FIk1xThy:YFP/paclitaxel

Fig. 5. Flk1 mediates the neuroprotective effects of VEGF in vivo: (A) averaged pinprick scores visualize the sensory deficit after subplantar paclitaxel injection. Upon subplantar challenge with paclitaxel, Thy:Flk1 ${ }^{\text {WT }}$ mice develop less neuropathy than WT mice (PBS WT versus PBS Thy:Flk1 $\left.{ }^{\text {WT; }} P=0.01, n=18-18\right)$. Subplantar administration of $10 \mu \mathrm{g}$ VEGF almost fully protects Thy:FIk1 ${ }^{\text {WT }}$ mice against paclitaxel-induced hypo-algesia (PBS Thy:Flk1 ${ }^{\text {WT }}$ versus VEGF Thy:Flk1 ${ }^{\text {WT }} ; P=0.002 ; n>8$ per group). Notably, wild-type (WT) mice treated with VEGF display a similar response as Thy:Flk $1^{\text {WT }}$ mice without VEGF treatment (VEGF WT versus PBS Thy:Flk $1^{\text {WT }} P=0.18, n>8$ per group). (B) Thy:Flk $1^{\text {DN }}$ mice react similarly to subplantar paclitaxel as WT mice $(P=0.72 ; n=18-18)$, but recover more slowly $(P=0.049$ by Chi-square on day 6 after the last paclitaxel injection). Subplantar VEGF is largely ineffective in Thy:FIk $1^{\mathrm{DN}}$ mice (PBS Thy:FIk $1^{\mathrm{DN}}$ versus VEGF Thy:FIk1 $\left.1^{\mathrm{DN}} ;{ }^{\mathrm{P}}=0.21\right)$. (C-E) Multiphoton imaging of Thy:YFP $\times$ Thy:Flk $1^{\text {WT }}$ mice confirms less retrograde degeneration of sensory axons in Thy:YFP $\times$ Thy:Flk 1 WT mice after halting paclitaxel injections (YFP-positive area: $2.89 \pm 1.08 \%$ in Thy:YFP $\times$ Thy:Flk 1 WT mice versus $0.58 \pm 0.19 \%$ in Thy:YFP mice; $n=7-12$; $P=0.014)$.

(Fig. 5C-E), with no baseline differences in the amount of YFP + axons between Thy:YFP $\times$ Thy:Flk $1^{\text {WT }}$ foot pads and Thy:YFP foot pads before paclitaxel injections (data not shown). Intriguingly, VEGF treatment additionally protected Thy:FIk1 ${ }^{\text {WT }}$ mice (Fig. $5 \mathrm{~A}$ ) to such an extent that these mice even became completely resistant to paclitaxel. Notably, WT mice treated with VEGF displayed a response that was similar to that seen in Thy:Flk ${ }^{\mathrm{WT}}$ mice not receiving VEGF.

Although Thy: $F l k 1^{\text {DN }}$ mice challenged with paclitaxel initially developed a sensory deficit that was comparable to that of WT mice, Thy:Flk $1^{\mathrm{DN}}$ mice subsequently recovered more slowly from their deficit once paclitaxel injections were halted (Fig. 5B). Subplantar delivery of VEGF was also largely ineffective in Thy: $F l k 1^{\mathrm{DN}}$ mice, suggesting that direct neuroprotective effects through Flk1 are essential for the therapeutic effects of VEGF in this model. The observation that the perfused vessel area in Thy: Flk $1^{\mathrm{WT}}$ and Thy: Flk $1^{\mathrm{DN}}$ paws was similarly reduced as in WT mice paws (not shown), confirmed that VEGF exerts its therapeutic effects through Flk1mediated neuroprotection.

\section{VEGF-derived peptide protects against diabetes- and paclitaxel-induced peripheral neuropathies}

Recently a VEGF mimicking pentadecapeptide (QKpeptide) with similar in vitro and in vivo angiogenic properties as the full-length VEGF protein was synthesized (D'Andrea et al., 2005; Santulli et al., 2009; Finetti et al., 2012; Ziaco et al., 2012). Although we and others have shown that VEGF is neuroprotective, the potential therapeutic effect of this VEGF-derived peptide has not been studied before. Therefore, we first 
A

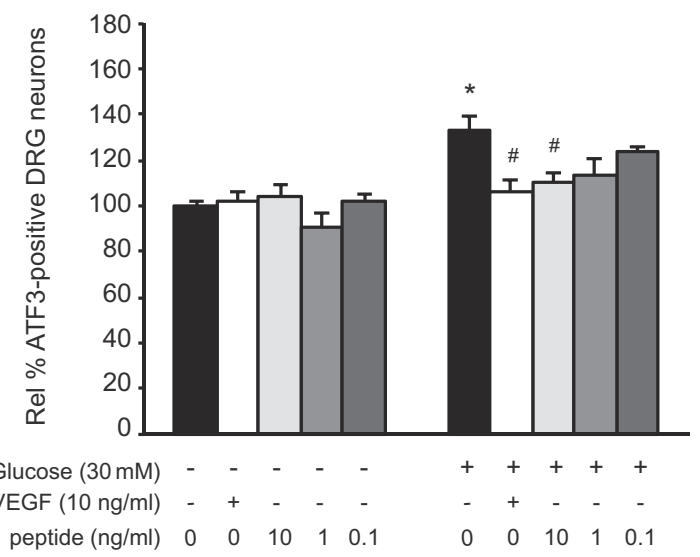

C

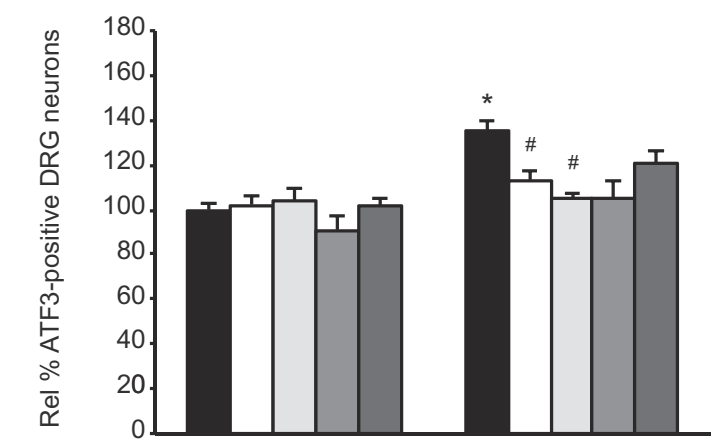

paclitaxel $(10 \mathrm{nM}) \quad-\quad-\quad-\quad-$

$\operatorname{VEGF}(10 \mathrm{ng} / \mathrm{ml}) \quad-\quad+\quad-\quad-$

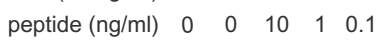

\section{E}

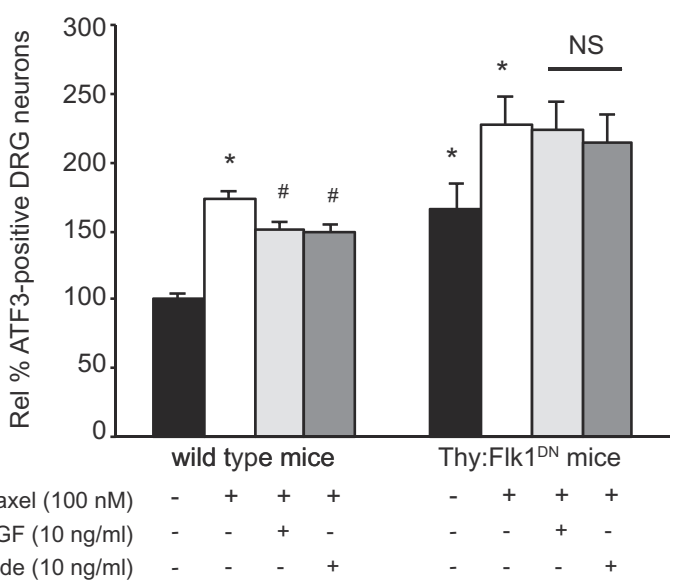

B

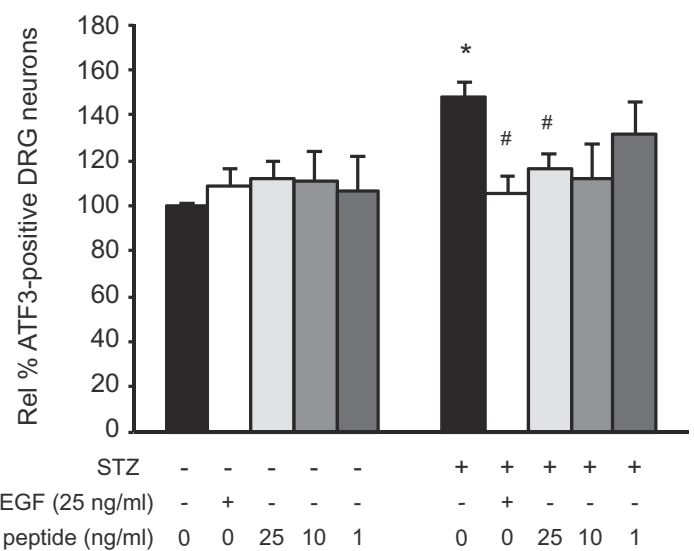

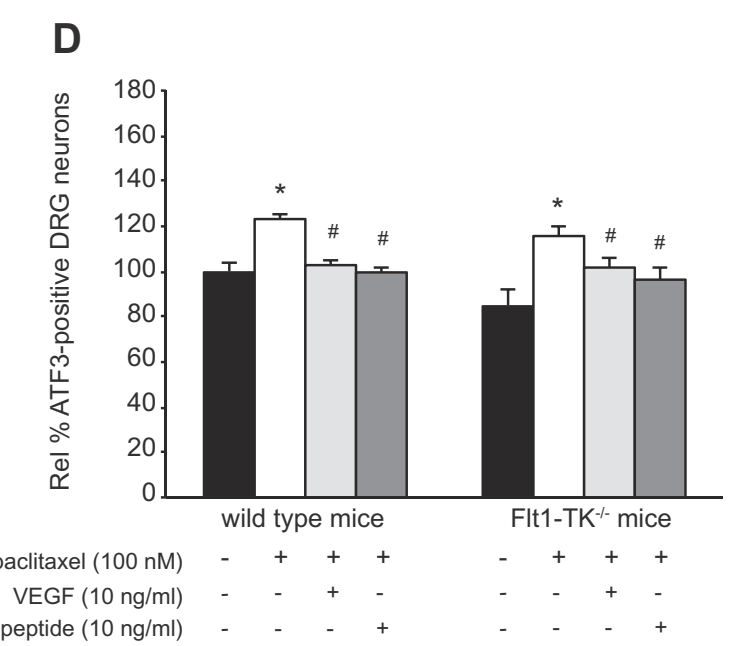

Fig. 6. VEGF-derived peptide protects against paclitaxel- and diabetes-induced neuropathies: (A) VEGF-derived peptide protects against glucoseinduced neuronal stress. Administration of VEGF or the VEGF-derived peptide (both $10 \mathrm{ng} / \mathrm{ml}$ ) protects DRG neurons against glucose-induced ATF3 increase ( $n=6$ wells from three rats). ${ }^{*} P<0.05$ versus non-treated control cultures and ${ }^{\#} P<0.05$ versus glucose-challenged DRG cultures (B) VEGF-derived peptide protects against diabetes-induced neuronal stress. Treatment of DRG neurons, isolated from diabetic rats, with VEGF or VEGF-derived peptide $\left(25 \mathrm{ng} / \mathrm{ml}\right.$ for both) reduces the number of ATF3-positive neurons ( $n=6$ wells from three rats). ${ }^{*} \mathrm{P}<0.05$ versus control cultures isolated from control mice and ${ }^{\#} P<0.05$ versus non-treated cultures isolated from diabetic rats. (C) VEGF-derived peptide protects against paclitaxel-induced neuronal stress. Both VEGF and the VEGF-derived peptide (both $10 \mathrm{ng} / \mathrm{ml}$ ) protect DRG neurons against paclitaxelinduced ATF3 increase ( $n=6$ wells from three rats). ${ }^{*} P<0.05$ versus non-treated control cultures and ${ }^{\#} P<0.05$ versus paclitaxel-challenged DRG cultures. (D, E) The VEGF-derived peptide is protective through the Flk1 receptor. VEGF-derived peptide (10 ng/ml) protects DRG neurons from wild-type mice and Flt-TK ${ }^{-l-}$ mice (D) (defective Flt1 receptor), but not from Thy:Flk $1^{\text {DN }}$ mice (E) (defective neuronal Flk1 receptor) against paclitaxel-induced ATF3 increase, similarly as the full-length VEGF protein $(10 \mathrm{ng} / \mathrm{ml}) .{ }^{*} P<0.05$ versus non-treated control cultures and ${ }^{\#} P<0.05$ versus paclitaxel-challenged DRG cultures. 
explored the effect of this peptide on hyperglycemiainduced neuronal stress. DRG neurons dissected from control rats and triggered with glucose or DRG neurons isolated from diabetic rats were treated for $24 \mathrm{~h}$ with different concentrations of VEGF or the VEGF-derived peptide. VEGF-derived peptide, just like the full-length protein, significantly reduced the number of ATF3positive DRG neurons (Fig. 6A, B). Additionally, the VEGF-derived peptide also protected paclitaxelchallenged rat DRG neurons against neuronal stress. The effect was identical to that of the full-length protein (Fig. 6C).

To evaluate which of the VEGF receptors (FIk1 or FIt1) mediated the protective effects of the peptide, DRG neurons were isolated from transgenic mice overexpressing a tyrosine kinase dead Flt1 receptor (Flt-TK ${ }^{-1-}$ mice) or overexpressing the DN Flk1 receptor (Thy:Flk1 ${ }^{\mathrm{DN}}$ mice) on neurons. DRG neurons from these transgenic mice and their littermate controls were challenged with paclitaxel and PBS, VEGF or the VEGF-derived peptide. Both VEGF and the VEGFderived peptide reduced neuronal stress in paclitaxelchallenged control and Flt- $\mathrm{TK}^{-1-}$ neurons (diminished Flt1 receptor, Fig. 6D), but not in Thy:Flk $1^{\mathrm{DN}}$ neurons (truncated Flk1 receptor, Fig. 6E), suggesting that the neuroprotective effects of the VEGF-derived peptide are mediated through the Flk1 receptor, but not the Flt1 receptor.

\section{DISCUSSION}

Almost 30 years ago, the vascular endothelial growth factor or VEGF was originally purified as a growth factor capable of increasing vascular permeability and endothelial cell proliferation (Senger et al., 1983). However, more recent findings have disclosed a more pluripotent nature of VEGF, in particular in the nervous system. In vitro evidence is accumulating that VEGF exerts a direct trophic and protective role on different types of neurons and supporting cells (reviewed in Ruiz de Almodovar et al. (2009)). In light of the emerging recognition of VEGF as a novel neuroprotective factor, we hypothesized a direct neuroprotective role for VEGF and VEGF-derived peptides in diabetes- and paclitaxelinduced peripheral neuropathies. Although a role for VEGF in peripheral neuropathies in vivo has been described previously, these effects were mainly attributed to its vessel-regenerating capacities (Schratzberger et al., 2001; Kirchmair et al., 2007). In the present study, we confirm the therapeutic potential of VEGF and provide evidence for its direct protective effects on sensory neurons.

In a first set of experiments we evaluated the therapeutic potential in diabetes-induced peripheral neuropathy. To study in vitro and ex vivo effects of VEGF, we used a model in which hyperglycemia is known to cause increased expression of ATF3, a generally accepted marker for neuronal stress (Tsujino et al., 2000; Shortland et al., 2006; Peeraer et al., 2011). We found that VEGF decreased neuronal stress levels in DRG neurons challenged with a high concentration of glucose or dissected from diabetic animals. Additionally, VEGF also restored hyperglycemia-induced mitochondrial dysfunction (Srinivasan et al., 2000), another hallmark of diabetic neuropathy. We confirmed these results in vivo by injecting VEGF protein subplantarily in a diabetic STZinduced neuropathy model. Animals receiving VEGF had less mechanical hyperalgesia than control-treated animals and DRG neurons dissected from these VEGFinjected animals also displayed reduced ATF3 levels compared to PBS-injected animals, suggesting a direct protective role of VEGF on the neurons in vivo. Notably, ATF3 expression levels were also decreased in DRG neurons related to the non-injected paw, although without significantly improving the nociceptive behavior in this non-injected paw. Possibly the duration or dose of VEGF treatment or the amount of animals was not sufficient to see a significant difference in nociceptive behavior in the contralateral paw. Further studies might be useful to further investigate these observations. Our results are consistent with a recently conducted clinical trial in which intramuscular VEGF gene therapy improved symptoms of diabetic neuropathy in humans (Ropper et al., 2009). To study whether VEGF receptor 2 (or Flk1) mediated the neuroprotective effects of VEGF, a monoclonal rat-anti mouse Flk1 antibody (DC101) was used in combination with VEGF in the in vitro neuronal stress model. This combination resulted in the loss of the neuroprotective effects pointing to the importance of Flk1 in mediating the therapeutic potential of VEGF. These results are consistent with previous findings showing direct protective effects of VEGF and Flk1 on paclitaxelinduced neurotoxic effects through upregulation of Bcl-2 (Verheyen et al., 2012). Bcl-2 levels were shown reduced in diabetic neuropathy (Srinivasan et al., 2000). Therefore, VEGF application to hyperglycemic DRG neurons and Flk1 activation might restore the depleted $\mathrm{Bcl}-2$ levels, resulting in the protection of mitochondria and depolymerization of $\alpha$-tubulin (Knipling and Wolff, 2006).

To validate and confirm the therapeutic role of VEGF in another neuropathy model in vivo, we subplantarily administered VEGF in a paclitaxel-induced hypo-algesia model, in which paclitaxel had also been injected subplantarily (Wilson et al., 2006). In both rats and mice, VEGF reduced the paclitaxel-induced sensory deficit and protected both nerves and vessel perfusion, which could be visualized using different in vivo imaging techniques. Notably, the effect of VEGF was comparable in size to that of GDNF - an archetypical growth factor known to exert neuro-specific effects without affecting the vasculature. Previous studies have shown that experimental neuropathies induced by paclitaxel and other toxic agents might benefit from systemic VEGF treatments (Kirchmair et al., 2005, 2007). However, the translation into clinical practice of systemic VEGF for the treatment of peripheral neuropathies is severely compromised by the concern that systemic VEGF accelerates tumor growth. Our findings illustrate that a more local, subplantar delivery 
of VEGF to the nerve endings diffuses much less into the systemic circulation, and hence constitutes a valid and less controversial alternative. In addition, subplantar VEGF delivery is a safe approach that does not trigger undesired effects in the footpad, as previously reported for NGF (Dyck et al., 1997) and GDNF (Malin et al., 2006). Our findings may thus be of prime interest when using locally delivered VEGF in peripheral neuropathies. Also in this model of neuropathy, the neuroprotective effects of VEGF are mediated through the Flk1 receptor. Mice that overexpressed the neuronal Flk1 receptor and were challenged with subplantar paclitaxel showed a similar reduction in sensory deficit to that observed in WT paclitaxel-challenged mice. On the other hand, mice overexpressing a DN Flk1 receptor did not respond to VEGF administration, confirming that Flk1 signaling is indispensable for the neuroprotective activities of VEGF.

Although we have shown that local VEGF application might be useful for the treatment of peripheral neuropathies, the treatment would be very expensive due to the nature of the native glycoprotein. To overcome this hurdle, a VEGF-derived peptide was recently generated with similar biological properties and VEGF receptor-binding capacities as the full-length VEGF protein (D'Andrea et al., 2005; Ziaco et al., 2012). Also in vivo, the peptide has been functionally and pharmacologically characterized as pro-angiogenic with positive effects on wound healing (Santulli et al., 2009; Finetti et al., 2012). Since VEGF protects neurons against diabetes- and paclitaxel-induced neuropathies, we hypothesized that the VEGF-derived peptide might have similar effects. In vitro, the peptide, just like the full-length protein, reduced neuronal stress in DRG neurons challenged with glucose or paclitaxel. Accordingly, ex vivo, both the peptide and the full-length protein protected DRG neurons isolated from diabetic animals against increased ATF3 levels. Finally, using transgenic mice with modified expression of Flt1 or Flk1 receptors, we were able to show that the neuroprotective activities of the VEGF-derived peptide, just like those of the full-length protein, can be attributed to Flk1.

We can conclude that both VEGF and the VEGFderived peptide show therapeutic potential for the treatment of diabetes- and paclitaxel-induced peripheral neuropathies. Furthermore, the VEGF-derived peptide might be a good and low-cost candidate to develop new therapeutics for the treatment of peripheral neuropathies and even other neurodegenerative diseases in which VEGF has shown therapeutic potential. More research is needed to determine which signaling pathways are activated by the peptide, triggering its neuroprotective properties.

\section{CONFLICTS OF INTEREST}

P.C. is named as co-inventor on a patent application regarding the use of VEGF to treat ALS. The Flanders Interuniversity Institute for Biotechnology (VIB) is one of the joint owners of this patent application, and the said patent application has been licensed to an outside company. Neither VIB nor any of the authors have equity stakes in the company. However, VIB and some of the authors stand to eventually receive royalties.

Acknowledgements-A.V., E.P., D.L., P.C., J-P.T., R.N., and T.M. wrote the manuscript. A.V., E.P., K.P., I.P. and M.S. performed experiments. D.L. is supported by the Research Foundation Flanders (FWO), Belgium; K.P. is supported by the Institute for the Promotion of Innovation by Science and Technology in Flanders (IWT). P.C. is supported by grants from the GSKE (Geneeskundige stichting Koningin Elisabeth) and excellence funding by the K.U. Leuven (Methusalem). This project is partly funded by a 'Research \& Development' grant of the governmental Institute for Science and Technology (IWT) for the promotion of research between universities (D. Lambrechts, K.U. Leuven, Belgium) and industry (T. Meert and R. Nuydens, Janssen Research \& Development, Beerse, Belgium).

\section{REFERENCES}

Apfel SC (1999) Neurotrophic factors and diabetic peripheral neuropathy. Eur Neurol 41(Suppl. 1):27-34.

Benjamin LE, Keshet E (1997) Conditional switching of vascular endothelial growth factor (VEGF) expression in tumors: induction of endothelial cell shedding and regression of hemangioblastomalike vessels by VEGF withdrawal. Proc Natl Acad Sci U S A 94:8761-8766

Christianson JA, Riekhof JT, Wright DE (2003) Restorative effects of neurotrophin treatment on diabetes-induced cutaneous axon loss in mice. Exp Neurol 179:188-199.

D'Andrea LD, laccarino G, Fattorusso R, Sorriento D, Carannante C, Capasso D, Trimarco B, Pedone C (2005) Targeting angiogenesis: structural characterization and biological properties of a de novo engineered VEGF mimicking peptide. Proc Natl Acad Sci U S A 102:14215-14220.

Del Bo R, Ghezzi S, Scarpini E, Bresolin N, Comi GP (2009) VEGF genetic variability is associated with increased risk of developing Alzheimer's disease. J Neurol Sci 283:66-68.

Dhondt J, Peeraer E, Verheyen A, Nuydens R, Buysschaert I, Poesen K, Van Geyte K, Beerens M, Shibuya M, Haigh JJ, Meert T, Carmeliet P, Lambrechts D (2011) Neuronal FLT1 receptor and its selective ligand VEGF-B protect against retrograde degeneration of sensory neurons. FASEB J 25:1461-1473.

Dvorak HF, Brown LF, Detmar M, Dvorak AM (1995) Vascular permeability factor/vascular endothelial growth factor, microvascular hyperpermeability, and angiogenesis. Am J Pathol 146:1029-1039.

Dyck PJ, Peroutka S, Rask C, Burton E, Baker MK, Lehman KA, Gillen DA, Hokanson JL, O'Brien PC (1997) Intradermal recombinant human nerve growth factor induces pressure allodynia and lowered heat-pain threshold in humans. Neurology 48:501-505.

Ferrara N, Gerber HP, LeCouter J (2003) The biology of VEGF and its receptors. Nat Med 9:669-676.

Finetti F, Basile A, Capasso D, Di Gaetano S, Di Stasi R, Pascale M, Turco CM, Ziche M, Morbidelli L, D'Andrea LD (2012) Functional and pharmacological characterization of a VEGF mimetic peptide on reparative angiogenesis. Biochem Pharmacol 84:303-311.

Gerber HP, Dixit V, Ferrara N (1998) Vascular endothelial growth factor induces expression of the antiapoptotic proteins $\mathrm{Bcl}-2$ and A1 in vascular endothelial cells. J Biol Chem 273:13313-13316.

Hirai A, Yasuda H, Joko M, Maeda T, Kikkawa R (2000) Evaluation of diabetic neuropathy through the quantitation of cutaneous nerves. J Neurol Sci 172:55-62.

Kirchmair R, Walter DH, li M, Rittig K, Tietz AB, Murayama T, Emanueli C, Silver M, Wecker A, Amant C, Schratzberger P, Yoon YS, Weber A, Panagiotou E, Rosen KM, Bahlmann FH, Adelman LS, Weinberg DH, Ropper AH, Isner JM, Losordo DW 
(2005) Antiangiogenesis mediates cisplatin-induced peripheral neuropathy: attenuation or reversal by local vascular endothelial growth factor gene therapy without augmenting tumor growth. Circulation 111:2662-2670.

Kirchmair R, Tietz AB, Panagiotou E, Walter DH, Silver M, Yoon YS, Schratzberger $\mathrm{P}$, Weber A, Kusano K, Weinberg DH, Ropper AH, Isner JM, Losordo DW (2007) Therapeutic angiogenesis inhibits or rescues chemotherapy-induced peripheral neuropathy: taxoland thalidomide-induced injury of vasa nervorum is ameliorated by VEGF. Mol Ther 15:69-75.

Knipling L, Wolff $\mathrm{J}$ (2006) Direct interaction of Bcl-2 proteins with tubulin. Biochem Biophys Res Commun 341:433-439.

Lauria G, Lombardi R, Borgna M, Penza P, Bianchi R, Savino C, Canta A, Nicolini G, Marmiroli P, Cavaletti G (2005) Intraepidermal nerve fiber density in rat foot pad: neuropathologic-neurophysiologic correlation. J Peripher Nerv Syst 10:202-208.

Leung DW, Cachianes G, Kuang WJ, Goeddel DV, Ferrara N (1989) Vascular endothelial growth factor is a secreted angiogenic mitogen. Science 246:1306-1309.

Malin SA, Molliver DC, Koerber HR, Cornuet P, Frye R, Albers KM, Davis BM (2006) Glial cell line-derived neurotrophic factor family members sensitize nociceptors in vitro and produce thermal hyperalgesia in vivo. J Neurosci 26:8588-8599.

Oosthuyse B, Moons L, Storkebaum E, Beck H, Nuyens D, Brusselmans K, Van Dorpe J, Hellings $P$, Gorselink M, Heymans S, Theilmeier G, Dewerchin M, Laudenbach V, Vermylen P, Raat H, Acker T, Vleminckx V, Van Den Bosch L, Cashman N, Fujisawa H, Drost MR, Sciot R, Bruyninckx F, Hicklin DJ, Ince C, Gressens $\mathrm{P}$, Lupu $\mathrm{F}$, Plate $\mathrm{KH}$, Robberecht W, Herbert JM, Collen D, Carmeliet P (2001) Deletion of the hypoxiaresponse element in the vascular endothelial growth factor promoter causes motor neuron degeneration. Nat Genet 28:131-138.

Peeraer E, Van Lutsenborg A, Verheyen A, De Jongh R, Nuydens R, Meert TF (2011) Pharmacological evaluation of rat dorsal root ganglion neurons as an in vitro model for diabetic neuropathy. $\mathrm{J}$ Pain Res 4:55-65.

Ropper AH, Gorson KC, Gooch CL, Weinberg DH, Pieczek A, Ware JH, Kershen J, Rogers A, Simovic D, Schratzberger P, Kirchmair $R$, Losordo D (2009) Vascular endothelial growth factor gene transfer for diabetic polyneuropathy: a randomized, doubleblinded trial. Ann Neurol 65:386-393.

Rowinsky EK (1993) Clinical pharmacology of Taxol. J Natl Cancer Inst Monogr 15:25-37.

Ruiz de Almodovar C, Lambrechts D, Mazzone M, Carmeliet $\mathrm{P}$ (2009) Role and therapeutic potential of VEGF in the nervous system. Physiol Rev 89:607-648.

Santulli G, Ciccarelli M, Palumbo G, Campanile A, Galasso G, Ziaco B, Altobelli GG, Cimini V, Piscione F, D'Andrea LD, Pedone C, Trimarco B, laccarino $G$ (2009) In vivo properties of the proangiogenic peptide QK. J Transl Med 7:41.

Schratzberger P, Walter DH, Rittig K, Bahlmann FH, Pola R, Curry C, Silver M, Krainin JG, Weinberg DH, Ropper AH, Isner JM (2001) Reversal of experimental diabetic neuropathy by VEGF gene transfer. J Clin Invest 107:1083-1092.

Senger DR, Galli SJ, Dvorak AM, Perruzzi CA, Harvey VS, Dvorak HF (1983) Tumor cells secrete a vascular permeability factor that promotes accumulation of ascites fluid. Science 219:983-985.
Shortland PJ, Baytug B, Krzyzanowska A, McMahon SB, Priestley $\mathrm{JV}$, Averill S (2006) ATF3 expression in L4 dorsal root ganglion neurons after L5 spinal nerve transection. Eur J Neurosci 23:365-373.

Sondell M, Lundborg G, Kanje M (1999) Vascular endothelial growth factor has neurotrophic activity and stimulates axonal outgrowth, enhancing cell survival and Schwann cell proliferation in the peripheral nervous system. J Neurosci 19:5731-5740.

Sondell M, Sundler F, Kanje M (2000) Vascular endothelial growth factor is a neurotrophic factor which stimulates axonal outgrowth through the flk-1 receptor. Eur J Neurosci 12:4243-4254.

Srinivasan S, Stevens M, Wiley JW (2000) Diabetic peripheral neuropathy: evidence for apoptosis and associated mitochondrial dysfunction. Diabetes 49:1932-1938.

Storkebaum E, Lambrechts D, Dewerchin M, Moreno-Murciano MP, Appelmans S, Oh H, Van Damme P, Rutten B, Man WY, De Mol M, Wyns S, Manka D, Vermeulen K, Van Den Bosch L, Mertens N, Schmitz C, Robberecht W, Conway EM, Collen D, Moons L, Carmeliet $P$ (2005) Treatment of motoneuron degeneration by intracerebroventricular delivery of VEGF in a rat model of ALS. Nat Neurosci 8:85-92.

Tessler S, Rockwell P, Hicklin D, Cohen T, Levi BZ, Witte L, Lemischka IR, Neufeld G (1994) Heparin modulates the interaction of VEGF165 with soluble and cell associated flk-1 receptors. J Biol Chem 269:12456-12461.

Tschachler E, Reinisch CM, Mayer C, Paiha K, Lassmann H, Weninger W (2004) Sheet preparations expose the dermal nerve plexus of human skin and render the dermal nerve end organ accessible to extensive analysis. J Invest Dermatol 122:177-182.

Tsujino $\mathrm{H}$, Kondo E, Fukuoka T, Dai $\mathrm{Y}$, Tokunaga A, Miki K, Yonenobu K, Ochi T, Noguchi K (2000) Activating transcription factor 3 (ATF3) induction by axotomy in sensory and motoneurons: A novel neuronal marker of nerve injury. Mol Cell Neurosci 15:170-182.

Verheyen A, Peeraer E, Nuydens R, Dhondt J, Poesen K, Pintelon I, Daniels A, Timmermans J-P, Meert T, Carmeliet P, Lambrechts D (2012) Systemic anti-vascular endothelial growth factor therapies induce a painful sensory neuropathy. Brain 135:2629-2641.

Wang YQ, Cui HR, Yang SZ, Sun HP, Qiu MH, Feng XY, Sun FY (2009) VEGF enhance cortical newborn neurons and their neurite development in adult rat brain after cerebral ischemia. Neurochem Int 55:629-636.

Wilson K, Geenen F, Biermans R, Nuydens R, Meert T (2006) Sensory dysfunctions after topical application of cytostatics: a new model for the study of peripheral neuropathies. Int $J$ Neuroprot Neuroregener 3:31-36.

Yasuhara T, Shingo T, Muraoka K, Kameda M, Agari T, Wen Ji Y, Hayase H, Hamada H, Borlongan CV, Date I (2005) Neurorescue effects of VEGF on a rat model of Parkinson's disease. Brain Res 1053:10-18.

Ziaco B, Diana D, Capasso D, Palumbo R, Celentano V, Di Stasi R, Fattorusso R, D'Andrea LD (2012) C-terminal truncation of Vascular Endothelial Growth Factor mimetic helical peptide preserves structural and receptor binding properties. Biochem Biophys Res Commun 424:290-294. 